\title{
Stratigraphical and Structural Analyses of the Sagrma (Sagerma) Anticline, Sulaimani Area, Iraqi Kurdistan Region
}

\author{
Polla Azad Khanaqa ${ }^{1} \&$ Kamal Haji Karim ${ }^{2}$ \\ ${ }^{1}$ Kurdistan Institution for Strategic Studies and Scientific Research, Iraq \\ ${ }^{2}$ Department of Geology, university of Sulaimani, Kurdistan region, Iraq \\ Correspondence: Kamal Haji Karim, Department of Geology, University of Sulaimani, Sulaimani city, Kurdistan \\ Region, Iraq. Tel: 964-770-157-1445. E-mail: Karimgeology@yahoo.com
}

Received: October 16, 2015

Accepted: November 4, 2015

Online Published: November 26, 2015

doi:10.5539/jgg.v7n4p74

URL: http://dx.doi.org/10.5539/jgg.v7n4p74

\begin{abstract}
The Sagrma anticline is a name for two parallel series of mountain peaks that are separated by a deep, wide and elongate valley which has width and length of 2 and $40 \mathrm{~km}$ respectively. The valley is called Qopy Qaradagh and it is beautiful picnic area for the people of the nearby Qaradagh town and surrounding villages. The anticline is located $40 \mathrm{kms}$ to the south of Sulaimani city at the boundary between High and Low Folded Zones. Recently the anticline is subjected to intense geological and seismic survey for oil exploration and an oil well is drilled to depth of $3400 \mathrm{~m}$ without finding economic oil. The aim of the present study is updating the data about the stratigraphy and structure of the anticline with the critical review of the previous studies. It is also aimed to give the possible reasons for the absence of oil in the anticline. The Kolosh, Sinjar, Gercus (or Khurmala) and Pila Spi Formations are exposed in the core, lower limbs, middle limbs and upper limbs of the inner arc of anticline respectively. The Pila Spi, Oligocene rocks, and Lower Fars, and Upper Fars Formations are exposed along the upper, middle and lower part of the outer arc of the two limbs. The previously described Sagerma and Avanah Formations are not recorded in the present study and this is true for the previous growth strata (as a syn-sedimentary deformation) too. Structurally, the Sagrma anticline is a tight double plunging anticline and its northeastern limb steeper than southwestern one. The anticline is not formed by fault propagation fold as concluded previously but deformed by limb rotation by which a detachment fold is generated. The rotation has intensely deformed the core of the anticline and due to this deformation the possible existed oil is not preserved. The main detachment fold is further deformed into several smaller (parasitic) anticlines which they have either $\mathrm{Z}$ or $\mathrm{S}$ shape which can be called anticlinorium. The anticline is shorted, in some places, by a large lateral thrust.
\end{abstract}

Keywords: Sagrma anticline, Sagerma section, Qaradagh area, stratigraphy, structural analysis, Avanah Formation, Gercus Formation, Kolosh Formation, Sinjar Formation, Pila Spi Formation

\section{Introduction}

Qaradagh (or Sagrma) Mountain is located at south of the Qaradagh district and belongs to Sulaimani Governorate at Kurdistan Region, Northeast Iraq. The anticline is subjected to intense surface geological and geophysical study for oil exploration. On the anticline, an oil well is drilled to depth of $3400 \mathrm{~m}$ but economic accumulation is not found. The mountain (anticline) is located between High and Low Folded Zones of Buday (1980) and Jassim and Goff (2006). Sangaw and Darbandikhan towns are located at south and east of the mountain while the northwestern and southwestern ends of mountain are extending between latitude and longitude of 35o 27' 00.00" N, 45o 11' 23" E and 35o 06' 52" N, 45o 32' 22" E respectively. The mountain is surrounded by tens of villages; the famous ones are Karm China, Jafaran, Koshk, Astel, Zardalika, Sewsenan, Goshan, Dollan, Kasnazan, Balkha, Bani Murad, Hanara, Homar Qala villages (Fig.1). The mountain resembles crocodile in shape and has northwest-southeast trend and elongate as two parallel series of peak for about $40 \mathrm{~km}$ and has width and height of $2 \mathrm{~km}$ and $1700 \mathrm{~m}$ respectively. The two series are separated by deep and wide valley which is called Qopy Qaradagh and this main valley is compartmenized in to more than 8 smaller valleys. The runoff of these valleys is drained northwardly by more than eight emepheral streams which are following through deep v-shaped obsequent gorges and finally all merge with Dewana stream (Fig.1).

The valley subsequent and scored in the core of the anticline by differential erosion and it is famous picnic area and densely covered by oak forests. These gorges are dissecting the northern mountain series into several ridges 
which have the flatiron (Flat iron) shape. The northward draining is due to the low thickness of the northeastern limb of the anticline as compared to the southwestern one. The high thickness of the latter limb is attributed to facies change and repetition of the formation by thrusting or minor folding which later discussed in detail.

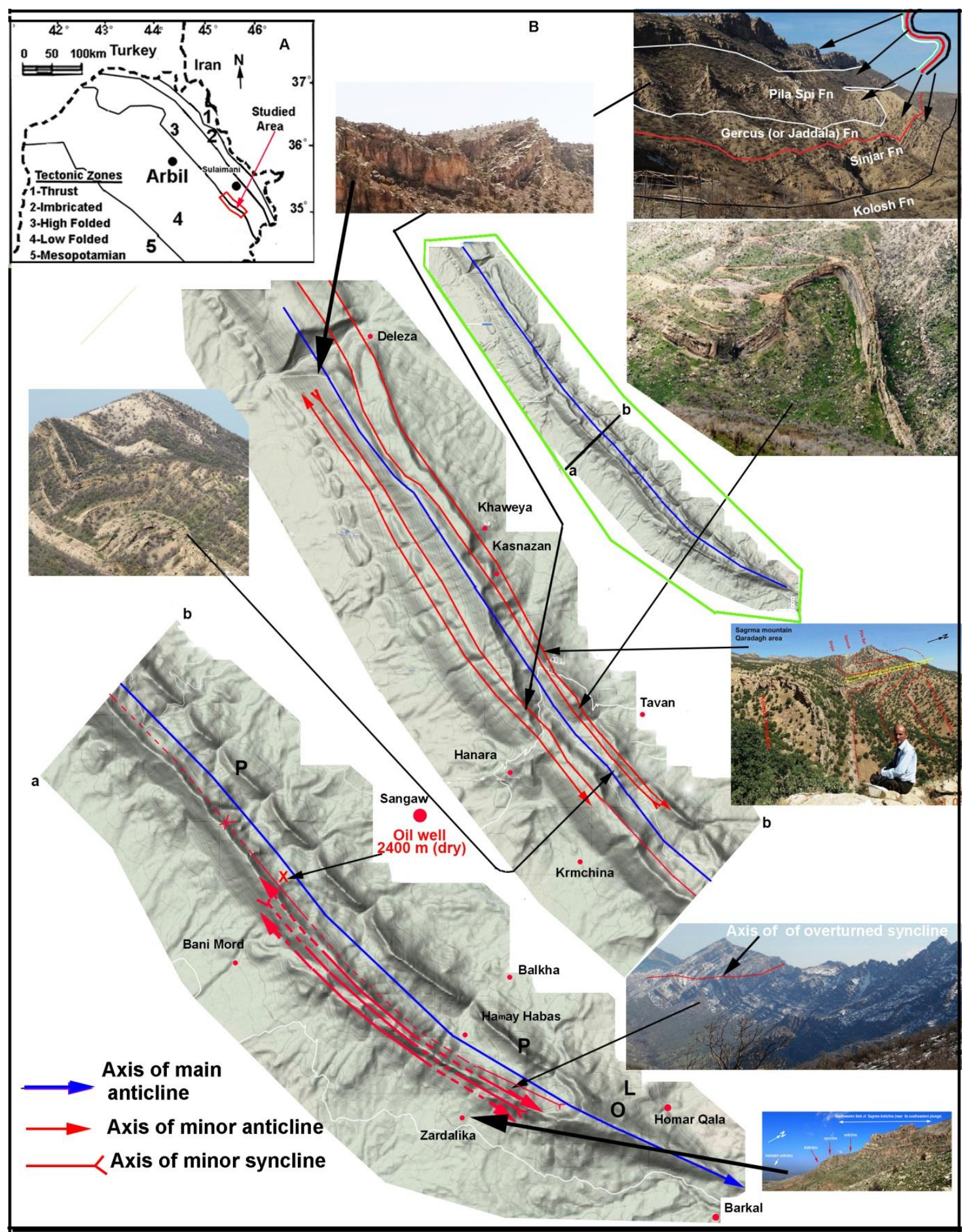

Figure 1. A) The location map of the studied area B) Geomorphology and some structural elements of the studied area 


\section{Result}

\subsection{Stratigraphy}

The stratigraphy of the anticline is complex and controversial as it represents the area of sudden facies and thickness changes in addition to relative structural complication. Previously Lawa (2004), Ghafur (2012) and Lawa and Ghafur (2015) have described a section under the name of Sagrma (or Sagerma). In these papers the latitude and longitude of the section are $35^{\circ} 18^{\prime} 20^{\prime \prime}$ and $45^{\circ} 16^{\prime} 55^{\prime \prime}$ respectively. According to these GPS values, the location is not clear because it is located on one a bed of Oligocene rocks and there is not outcrop of other formations that are described in the above three papers. However, in the present study, the section is found during field work by comparing the field photo of Lawa (2004) with its field equivalent (Fig.3 and 4)

\subsubsection{Kolosh Formation (Paleocene)}

The formation is the oldest exposed formation in the area which is occupies the core of the anticline (Fig.2). It consists of dark grey marl and sandstone and its thickness is not known but in the oil well its thickness was more than $500 \mathrm{~m}$ (Fig.5). This high thickness may be due to its softness and intense deformation by limb rotation of the anticline by which it has squeezed upward. It is overlain by Sinjar Formation which has gradational contact.

Lawa (2004, p226) has gave two different ideas about the boundary of the two formation on the southwest limb (He called it Sagerma Section). He referred to shallowing and progradation during deposition of the boundary. He mention the below paragraph: "The coarse grain sized siliciclastics increase upwards the section toward thin pebbly sandstone and conglomerate below the upper boundary which mostly consists of bioturbated by sandy shore habituates Skolithos ichnofossils, as well as the mass extinction of Paleocene fauna emphasized sea level fall before the boundary with the upper Ypresian Early Eocene carbonates of Sinjar Limestone Formation and indicate the termination of Paleocene third order cycle indicated by the progradational sacked sequence of the upper most parts." The same author, in the other paragraph, has indicated the boundary of the two formations as type 3 Sequence boundaries which denotes sea level rise or deepening or drowning unconformity. About this sequence boundary he mentioned the below paragraph in the page226:

"The lower sequence boundary with the Kolosh Formation is proposed have to be of great stratigraphic importance where the giant Gastropod, extensively bioturbated thick glauconitic sandy carbonate used as sequence Boundary of Type .3 ".

The latter author has concluded that the contact between the two formation is type one and type three sequence boundary in Sartak-Bamo and Sagerma section respectively. This means that at the distance of about $50 \mathrm{~km}$ the sea level was raised in the former place and lowered in the latter one which is not observed in the presented study.

\subsubsection{Sinjar Formation (Late Paleocene-Early Eocene)}

This formation consists of about 30 meters of grey to milky massive detrital and biogenic limestone and slightly dolomitized. Along both limbs of the anticline, it is relatively thin and more or less shares properties with Khurmala Formation. It has gradational contact with both Kolosh Formation and Gercus Formation. In the studied area, it only exposed along in inner arc of the both limps above the Kolosh Formation (Fig.2A). Its main fossils content is nummulites (Fig.2B), alveolina, with pelecypods and gastropods. The contact is conformable with both Kolosh and Gercus Formation.

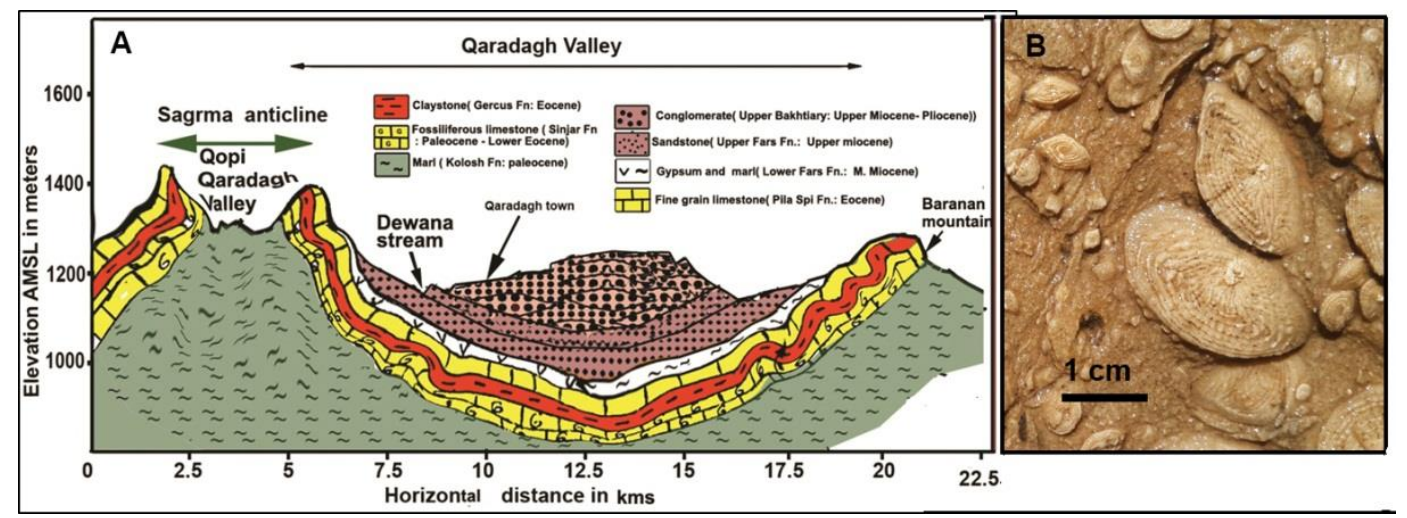

Figure 2. A) Geological cross section of the Sagrma anticline and Qaradagh valley, B) Nummultes in the Kolosh Formation in handspecimen 


\subsubsection{Gercus Formation}

In the studied area, the formation consists of sandstone, red claystone and grey marl and these lithologies, in some place, interfinger with marly or detrital limestone. The thickness of this formation is variable from place to another; it is about $35 \mathrm{~m}$ on northeastern limb while on the southwestern limb and in most place, it changes to Khurmal Formation (Fig.3) which is composed of detrital limestone and marly limestone with gypsum and resemble the Khurmala Formation which is described in Sartak Bamo area by (Karim, 1997). It is composed of red claystone, sandstone and lenses of conglomerate. Its boundary is gradational with underlying Sinjar Formation while it is unconformable with the overlying Pila Spi Formation as cited by Ameen (2006) who showed a bed of conglomerate between the two formations which about 4 meters thick.

\subsubsection{Sagerma (or Sagrma) Formation}

This formation is proposed by Lawa (2004) in his PhD thesis and indicated its type section (by photos) on the southwestern limb of Sagerma (or Sagrma) anticline at about $14 \mathrm{kms}$ to the southwest of Qaradagh town (Fig.1a). This section is located at the latitude and longitude of $35^{\circ} 20^{-} 01.57^{-} \mathrm{N}$ and $45^{\circ} 15^{\circ} 41.70^{\circ}$ E respectively.

The location and field photos that are published by the above author is checked by the present authors and it is proved that the claimed formation consists of Pila Spi Formation and equivalent of Gercus (Kurmala Formation) which are repeated by folding along the southwestern limb of Sargrma anticline (Fig. 3and 4)

In his thesis, Lawa (op cit) mentioned a name of a paper under the title of “. Lawa, F. A, 2004, in press: New proposed lithostratigraphic rock unit, Sagerma Formation of Middle Eocene age, Sulanimani District”. Moreover than that, the name of Sagerma Formation is appeared in abstracts by Amen (Lawa) (2008), Lawa, and Albayati (2008); and in Cenozoic Stratigraphic Column of Middle East by Al-Husseini (2008).Unfortunately, the published full text of the above latter four papers are not appeared yet. The occurrence of Khurmala Formation is mentioned by Karim (1997) in Sartak Bamo Area; about $25 \mathrm{~km}$ to the southeast of Darbandikhan town http:/kurdistan-geology.com/?p=384 . He referred to a succession of marly limestone (about $20 \mathrm{~m}$ thick) as Khurmala Formation above Sinjar Formation. He found Gypsum nodules and dwarfed fossils in it.

\subsubsection{Pila Spi Formation}

Two formations have significant effect on the geomorphological shape of the Sagrma anticline, the first one is Kolosh Formation which is deeply scored and formed the valley of Qopy Qaradagh due to its softness. The second one is Pila Spi Formation which forms the most erosion resistant rock along both limbs and makes up the highest ridges (peaks) around the anticline (Fig.1B). This formation can be seen along upper parts of the inner and outer arc of the both limbs and composed of about $120 \mathrm{~m}$ of white chalky and dolomitic limestone which is porous and marly in some interval. No fossils are visible but to the north of the studied area on the Branan mountain, Khanaqa (2012), has recorded (in some intervals) intraclasts, bioclasts, alage, coral and broyzoa. As mention before, Lawa (2004) has established Sagerma Formation across a part of the southwestern limb of anticline but the present study proved that is repetition of Pila Spi Formation by folding (Fig.3 and 4). Ibrahim (2009, p.174) has recorded, on the latter limb, growth strata between Upper Fars and Pila Spi Formations which will be discussed later.
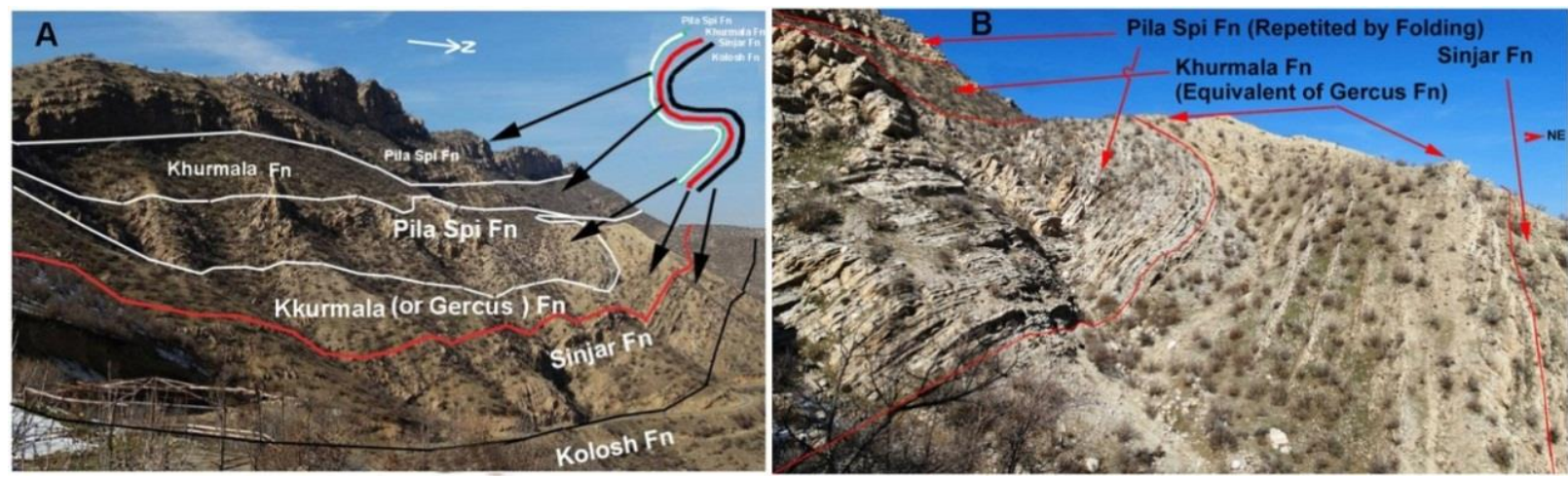

Figure 3. Stratigraphic differentiation of the inner arc of the southwestern limb Sagrma (Sagerma) anticline 1km to the Shekh Mohamad Kasanaziny garden. A) This photo shows the same view of the Lawa (2004, see the below photo). B) Close up of the repetition of the Pila Spi and Khurmala Formations 


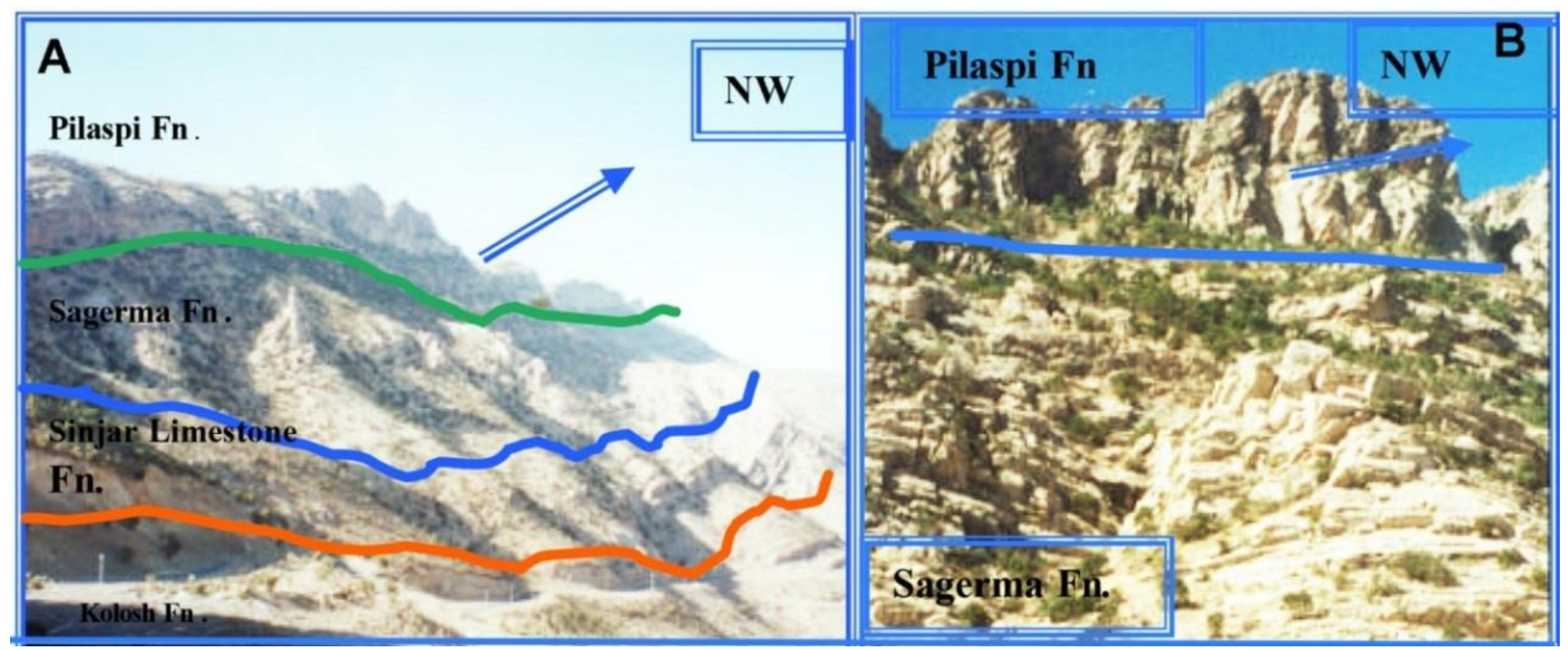

Figure 4. A) Sagerma Formation by Lawa (2004) which is assumed in the present study as repetition of Pila Spi and Khurmala Formation (see the above photo). B) Sagerma Formation by (lawa, 2004) which represents the middle area of the figure $\mathrm{A}$

\subsubsection{Avanah Formation}

In the type section, according to Bellen et al. (1959), this formation is composed of about $200 \mathrm{~m}$ of dolomitic limestone with alveolina and nummulite foraminiferas of Middle Eocene age. In the studied area is it recorded and described in detail stratigraphically by Ghafur (2012) and Lawa and Ghafur (2015) below Oligocene rocks. These authors have not indicated studied section (Sagrma section) accurately and without giving clear field photos. The studied section of the above to authors is found from photo given by Lawa (2004) for the Sagrma section. The field study does not proved the occurrence of the Avanah Formation as the lithology is nearly similar to the lithology of the Pila Spi and Alveolina and Nummulite forams are not recorded in the present study. In their boizonation chart, Ghafur (2012) and Lawa and Ghafur (2015) have not recorded the last two forams but they have recorded miliolid in all samples and Orbitolites complanatus in only 6 samples near Oligocene boundary. Therefor the presence of Avanah Formation in Sagrma section is not ascertained in present study.

\subsubsection{Oligocene Rocks}

These rocks are exposed as successions of about $10 \mathrm{~m}$ along the outer arc of the northeastern and southwestern limbs. It can be seen along the lower and upper parts of the former and latter limbs respectively. To the south of the studied area, the Oligocene rock successions are described in detail for the first time by Babashekh (2000), Kharajiany (2008), Ameen (2009) and Ghafor et al. (2014). Khanaqa et al. (2009) have extended the outcrops (or basin) limit of these successions into inside high Folded Zone. This extension is more than $15 \mathrm{~km}$ northward as compared to that indicated by Dunnington (1958) and Lawa et al. (2013). Khanaqa (op. cit.) has shown clear coral photos of a section on the northeastern limb of Sagrma anticline to south of Balkha Village. Lithologicaly, it consists of hard and massive milky limestone which contains, in some place, red spots and laminae. The succession is used for decoration stone and crashed for using as aggregate with white cement. It is located between Pila Spi and Lower Fars Formation and contains at least on limestone conglomerates.

Previously a section is studied across southwestern limb of Sagrma (or Sagerma) anticline by Ghafur (2012) and Lawa and Ghafur (2015) and the location is given by GPS and by photos, the problem is that in the GPS location only Oligocene rocks are exposed while the photo does not contain outcrop of the Oligocene.

\subsubsection{Lower Fars Formation}

The studied area represents the peripheral areas during deposition of the Lower Fars Formation (Middle Miocene) where the formation mainly consists of red claystone, gypsum, marl, sandstone and detrital limestone. Its thickness is about 20-70 meters and its lower boundary is unconformable and gradational with the underlying Oligocene succession and overlying Upper Fars Formation respectively.

Lawa et al. (2013, p.89) has published a photo of growth strata in Upper Fars Formation on the outer arc of the southwestern limb of Sagrma anticline at the latitude and longitude of $35^{\circ} 11^{-} 10.69^{\mp} \mathrm{N}$ and $45^{\circ} 20-32.94^{\mp} \mathrm{E}$. 
They added that the growth indicates onlap with Lower Fars Formation which represented by successively younger sandstone beds with variable dips within the former formation and gentler dips southwestward (Fig.6).They further added that the variation of the dips to gentler southward indicates the deformation front in the Miocene and defines the current boundary between the High and Low Zagros Fold-Thrust Zones. Similarly, Ibrahim (2009, p.174) had recorded, on the latter limb, growth strata and opposite to Lawa et al. (2013), he has supposed that growth strata are related to Pila Spi and Upper Fars Formations as growth and pre-growth strata respectively (Fig.7). About this depositional structure, during Tertiary, he mentioned this paragraph "The onlap relation can be seen in the field between the layers of the Upper Fars Formation (pre-growth strata) and the Pila Spi Formation (growth strata) that forms the cores of the Sagrma and Darbandi-Bazian anticlines. This onlap geometry indicates that during the deposition of the Tertiary foreland basin units, the folded structures were still uplifting and pushing the Tertiary units southwestwards which led to the variations in the dip amounts towards the foreland (SW)".
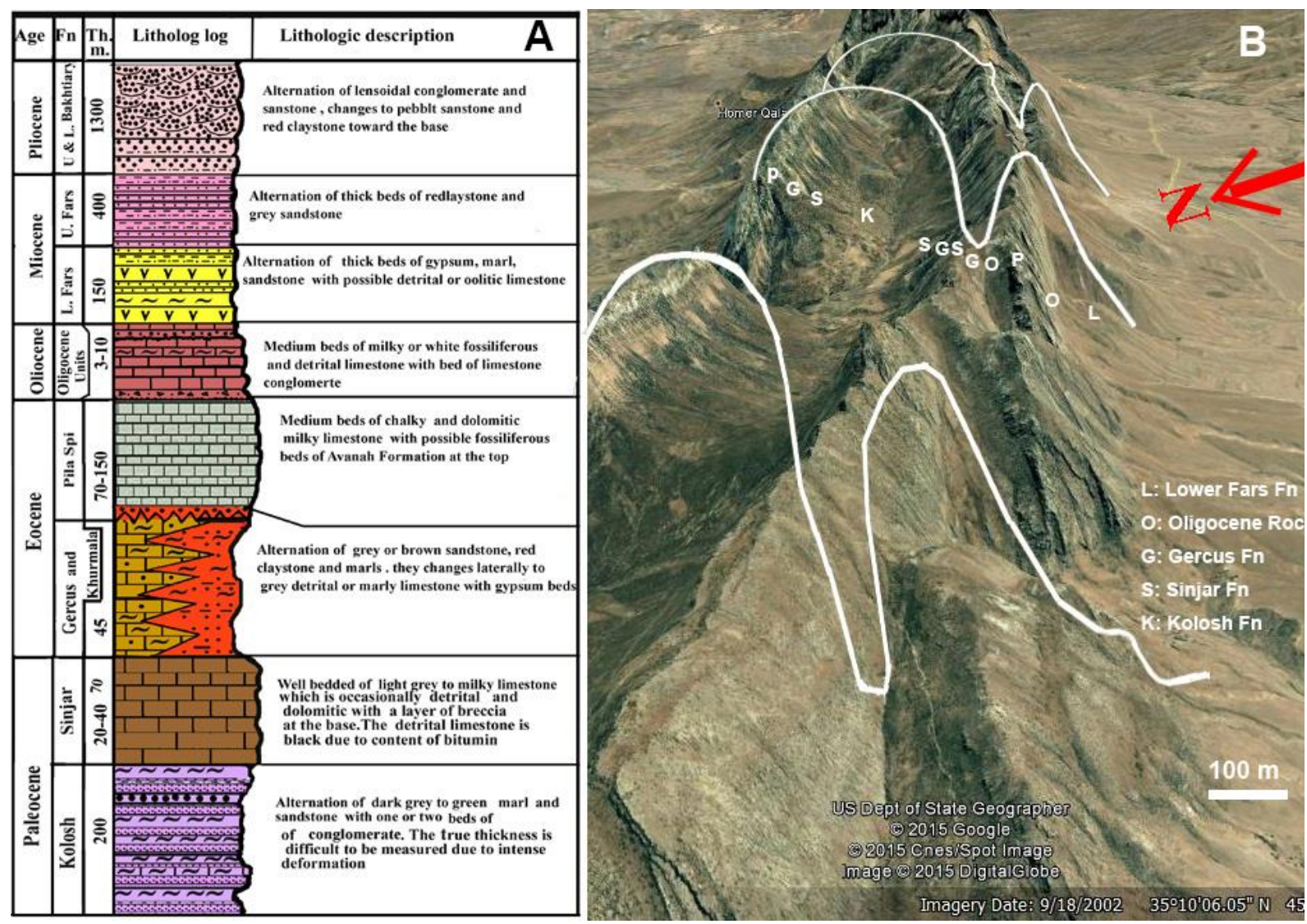

Figure 5. A) Stratigraphic column and-of the Sagrma anticline, B) Google image of the southeastern part of the anticline shows main and miner folds 


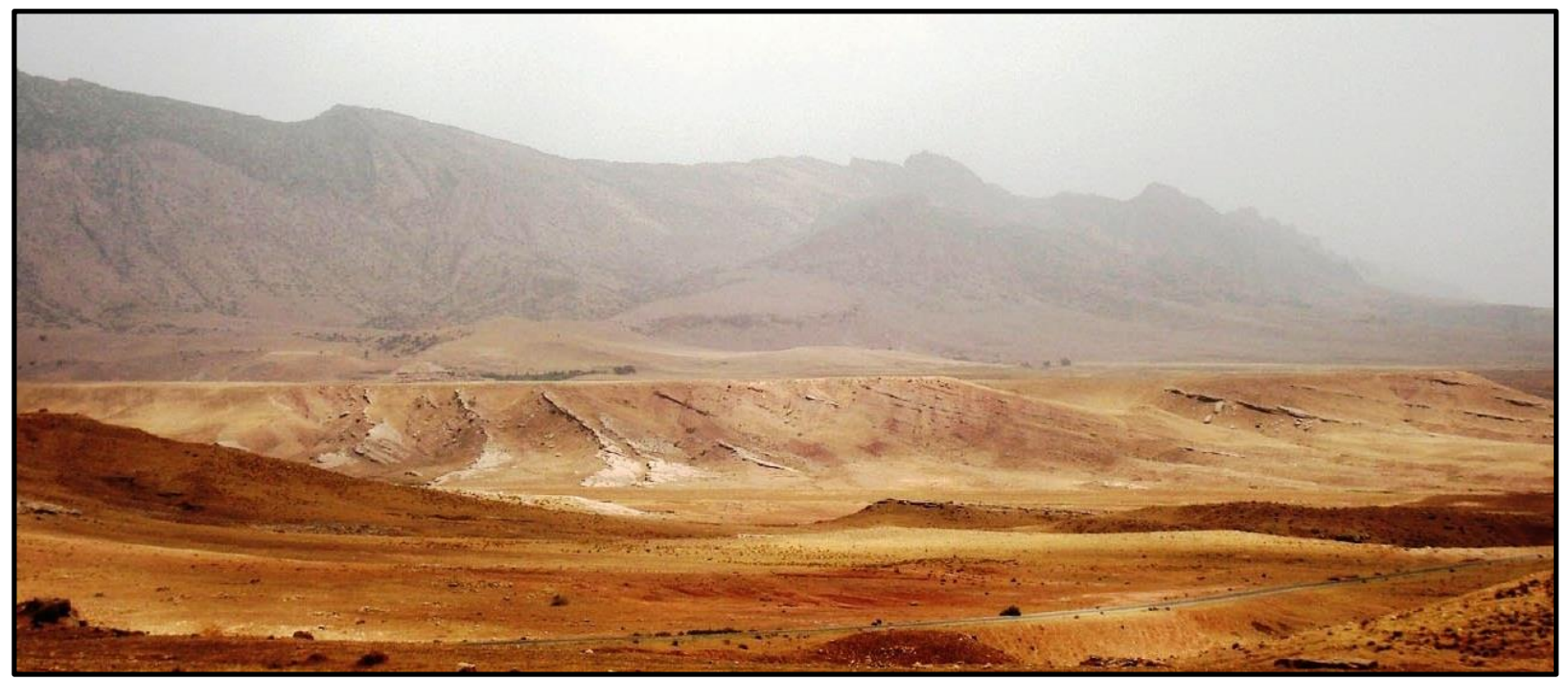

Figure 6. A photo of Lawa et al. (2013, p.89) at the latitude and longitude of $35^{\circ} 11^{-} 10.69^{=} \mathrm{N}$ and $45^{\circ} 20^{-} 32.94^{=}$

E respectively near Hazar and Bani Mord villages. They published it to show growth strata during Miocene. But the present study proved that is related to change of dip of syncline across its axis and limbs

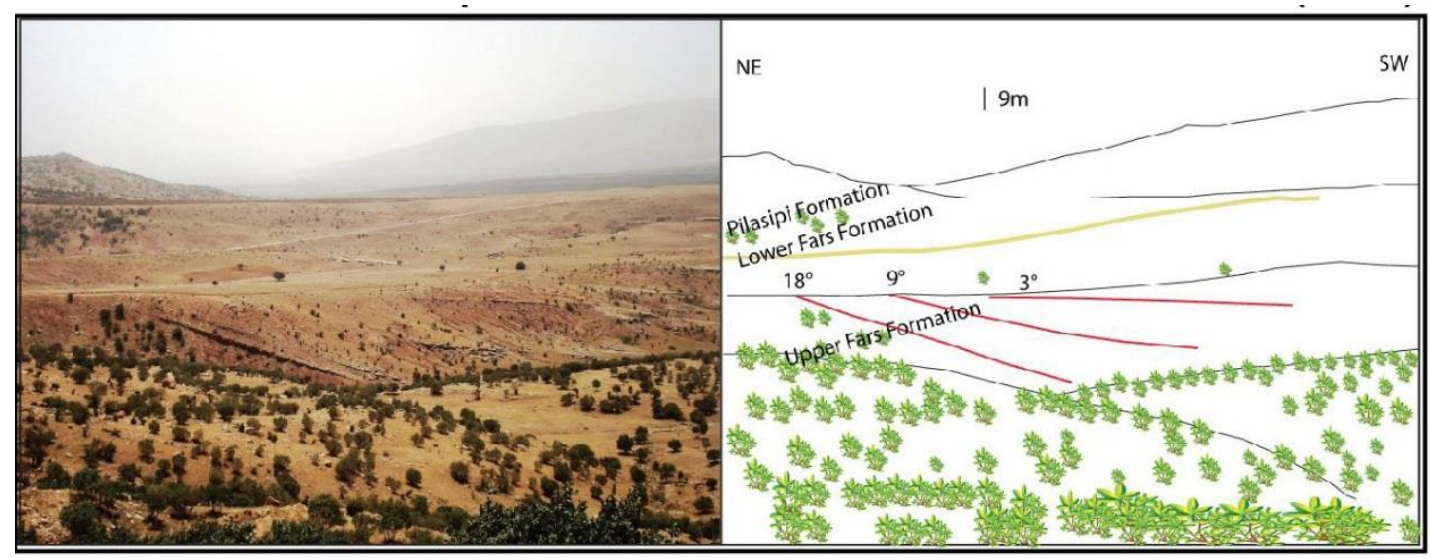

Figure 7. A photo of Ibrahim. (2009, p.174) near Sangaw town, shows growth strata between Pila Spi and Upper Fars Formations

\section{Disscussion}

\subsection{Growth Strata}

The growth strata of Lawa et al. (2013, p.89) in Upper Fars Formation on the outer arc of the southwestern limb of Sagrma anticline is not found in the present study, and the variation of the dip of the Upper Fars Formation to gentler degrees is due to the fact that the photo shown by above authors is located near the axis of the Sangaw syncline which is located between Sagrma and Ashdagh anticlines. The gentler dip in their photo (Fig.6 and 7) is located more or less near the axis of the syncline while the steeper one is located on the northeastern limp of the syncline (same as southwestern limb of Sargrma Anticline) (Fig.8). This explanation is true for the growth strata of Ibrahim (2009, p.174) on the southwestern limb of the Sagrma anticline, between Upper Fars and Pila Spi Formations (Fig.7). The change of the dip of Upper Fars (as appears from figure7) is due to change of the structure from syncline to anticline.

Ma, ala, (2008) has indicated the axis of the syncline at the location of the photo of Lawa et al.(2013). Therefore, the change of the dip of strata of a limb of a syncline from gentler to steeper across its axis is self-evident fact and must not be related to growth of the strata during sedimentation and must not attributed to presence of deformation front during Miocene. The deformation front never reached this place during Miocene because part of the Upper Bakhtiari was deposited during Pliocene. This means that during Pliocene the area was coastal area of the Zagros Foreland basin and no folding was started yet in the area. These growths are not appeared on the 
seismic profile of the anticline that is published in the web by Energy Pedia news (2015) (Fig.9). The growth strata that are indicated by Ibrahim (2009, p.174) and Lawa et al. (2013) must appear (if it is present) on the left top of the latter profile which is showing Sangaw syncline. Unfortunately, the profile does not show these growth strata.

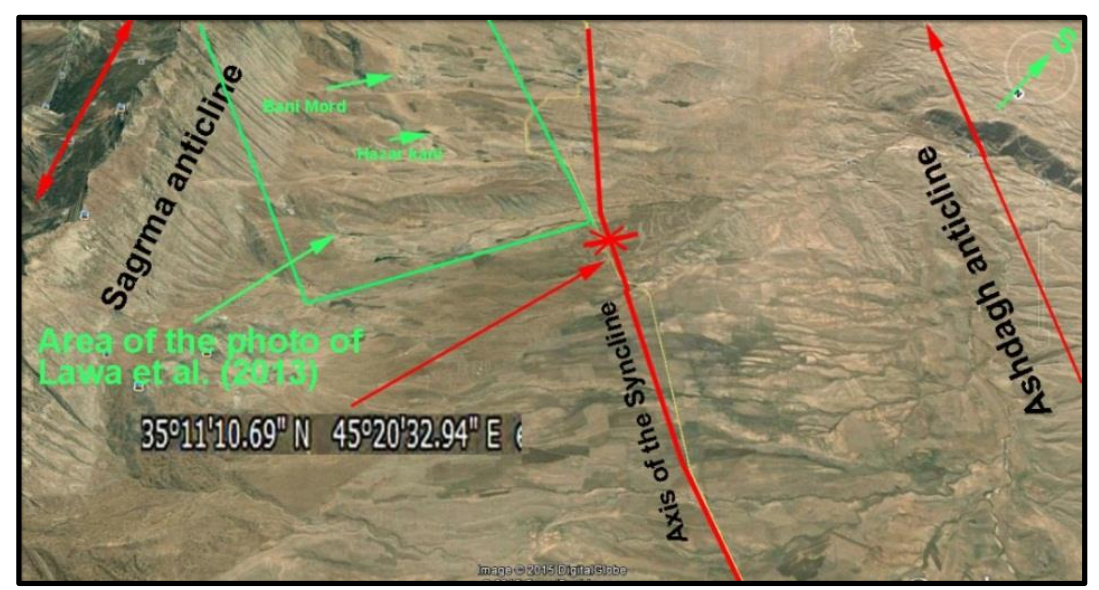

Figure 8. Sangaw syncline is evidence for the change of dip of the Upper Fars formation and it is not related to Growth strata during Miocene as cited by Lawa et al. (2013)

\subsection{Structural Analysis}

Structural and stratigraphical setting is two important variables in any folded area; the analytical accuracy of the two variables highly depends on each other. This is can help to avoid the confusion in establishment of the Sagrma Formation and assignment of growth strata of the Miocene age which are related to structural not syn-sedimentation. Therefore, depending on the section of stratigraphy, the structural analyses of the Sargma anticline are analyzed below.

Sagrma anticline is southeastern part of a large anticline called Darbandi Bazian-Sagrma-Qaradagh anticline by Al-Hakari (2011) which elongate for about $95 \mathrm{kms}$ along the boundary between High and Low Folded Zones. This anticline classified or shown as fault propagation fold by Ibrahim (2009, p.127) and later Al-Hakari, (2011, p.161) assumed same mechanic for folding too and draw a cross section to show its mechanic and Omer et al. (2015, p15) used the same figure for calculation of shortening (Fig.10A). The latter two studies have added that it formed by Zagros Mountain Front Fault (ZMFF) which is supposed to coincides (or emerge) near the lower part of the southwestern limb of the Sagrma anticline at the north of Sangaw and pass through Krmchna, Hanara, Banimord, Zardalika and Barkal villages. The fault nearly coincides with two locations that are mentioned to contain growth strata by Ibrahim (2009) and Lawa et al. (2013).

In the present study and during field work neither ZMFF nor growth strata are found. If the Sagrma anticline has been formed by Fault propagation, the Kirkuk anticline must be formed by the same mechanic. The comparison of the Kirkuk and Sagrma anticline with the study of Mitra (2003) doesn't show above mechanic of folding. The comparison show, disharmonic and lift-up detachment folds for the two anticlines respectively and the former anticline does not contain large fault (Fig.10B), therefor the Sagrma anticline is similar to the Kirkuk anticline but with more deformation. Moreover, when the classification of Mitra (2003) is applied, the small reverse fault near the crest of Kirkuk anticline is asymmetric faulted fold which form during increase of deformation due to existence of detachment gypsum beds (Fig.10B and D).

Recently, a low resolution seismic profile of the Sagrma anticline is published in the web by Energy Pedia news (2015) which was structurally has been interpreted. On this profile, an anticline and a main reverse fault is indicated which shows a fault propagation fold (Fig.10). The profile allows more than one interpretation and that of the present study is indicated by light green lines which show parasitic folding and the reverse fault is not expressed on it. On this profile the growth strata of Ibrahim (2009) and, Lawa et al (2013) are not appeared. 


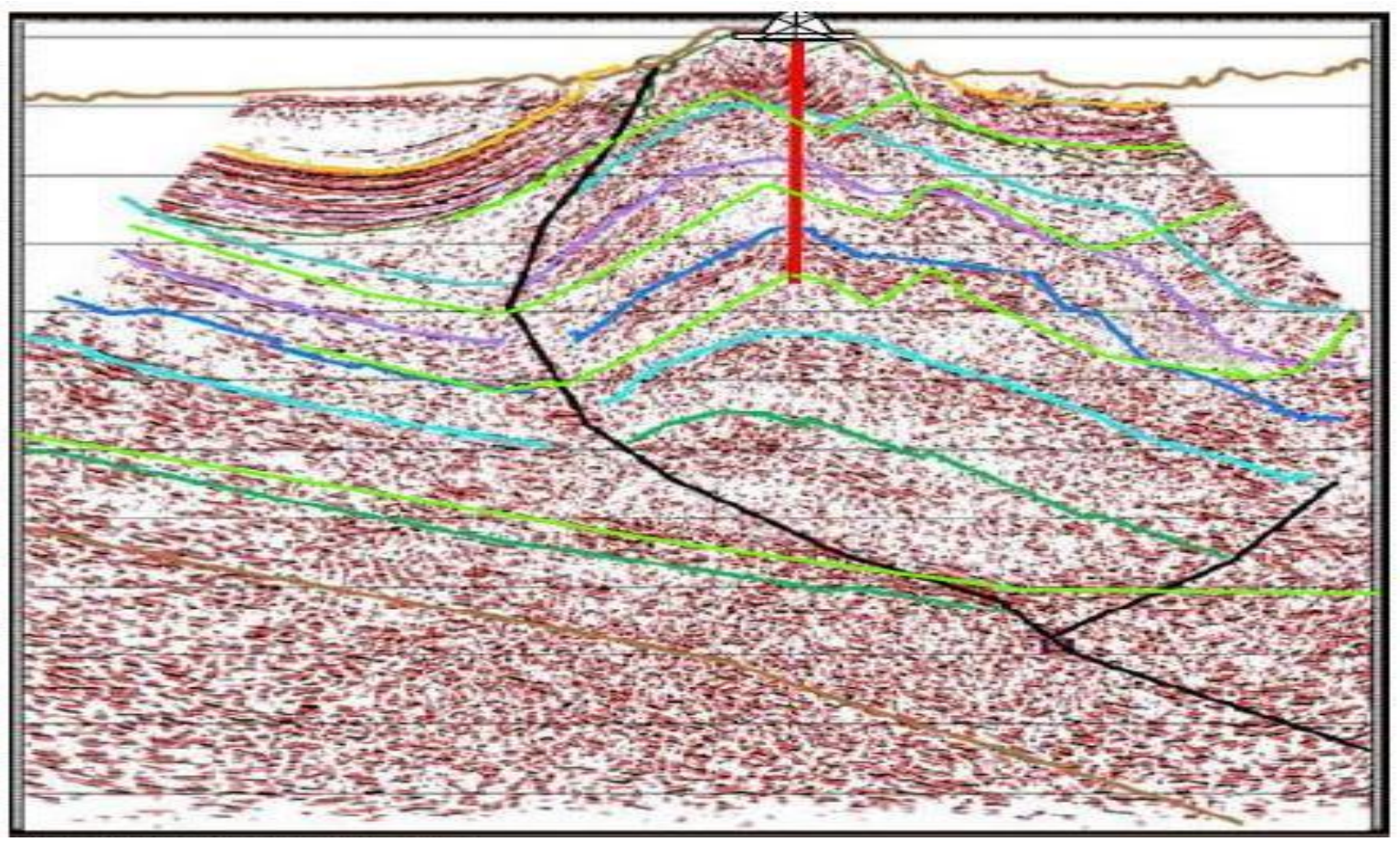

Figure 9. Seismic profile of the middle part of the Sagrma anticline (Energy Pedia news, 2015) the light green lines shows the interpretation of the present study which does not show reverse faulting

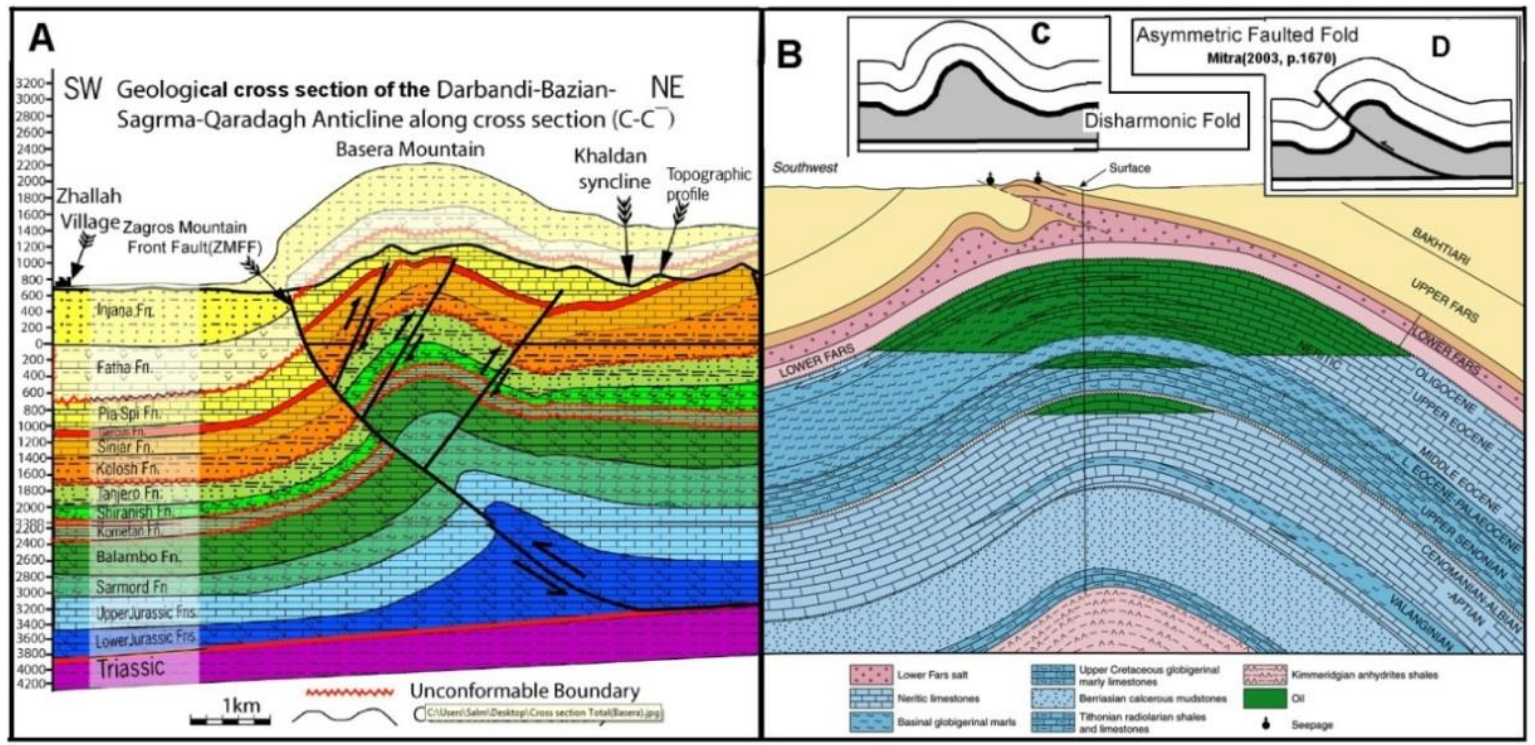

Figure 10. A) Geologic cross section of Sarma-Darbandi Bazian (Al-Hakari, 2011) and Omer et al. (2015) which assumed as fault propagation fault. B) Kirkuk anticline is detachment fold (disharmonic fold) formed by limb rotation not by Fault propagation fold. C) Disharmonic detachment fold (Mitra, 2003) which similar to Kirkuk anticline. D) Asymmetric faulted fold (Mira, 2003) which is similar to the faulted anticline near the crest of latter anticline

\subsection{Hanara Lateral Thrust Fault}

This fault is located $7 \mathrm{kms}$ to the northeast of the Sangaw town and $2 \mathrm{~km}$ to the north of Hanara village. Its trace on the earth is exposed on the Sagrma anticline along the paved road that passes the anticline and connected between Qaradagh and Sangaw towns. This fault is the largest in the area which is well expressed on both large and small scales. On both scales and on the surface, it is clear lateral thrust which has more than 500 meter of horizontal and 200m of vertical displacements (Fig.11). 
The horizontal displacement can be seen along the southeastern side of the Qopi Qaradagh valley near the Kani Bachka Spring (or Shekh Mohamad Kasnazany garden) on the road that crosses the valley to Sangaw town. At this locality, the rocks successions of southwestern limb of the anticline are separated into two parts of the northwestern and southeastern parts. The latter part is thrusted over the former part at an angle of about 15 degrees (Fig.11 and 12B). Stratigraphically, due to this over thrusting, the Kolosh Formation (Paleocene) is rested on the Anah or Baba Formation (Oligocene) succession (Fig.12A). The effect of this fault can be seen on the corresponding northeastern limb of the Sagrma anticline and appear as northeastern overturning of the strata of the limb. It is possible that this limb is more or less thrusted southeastwardly as can be seen from the figure (13).

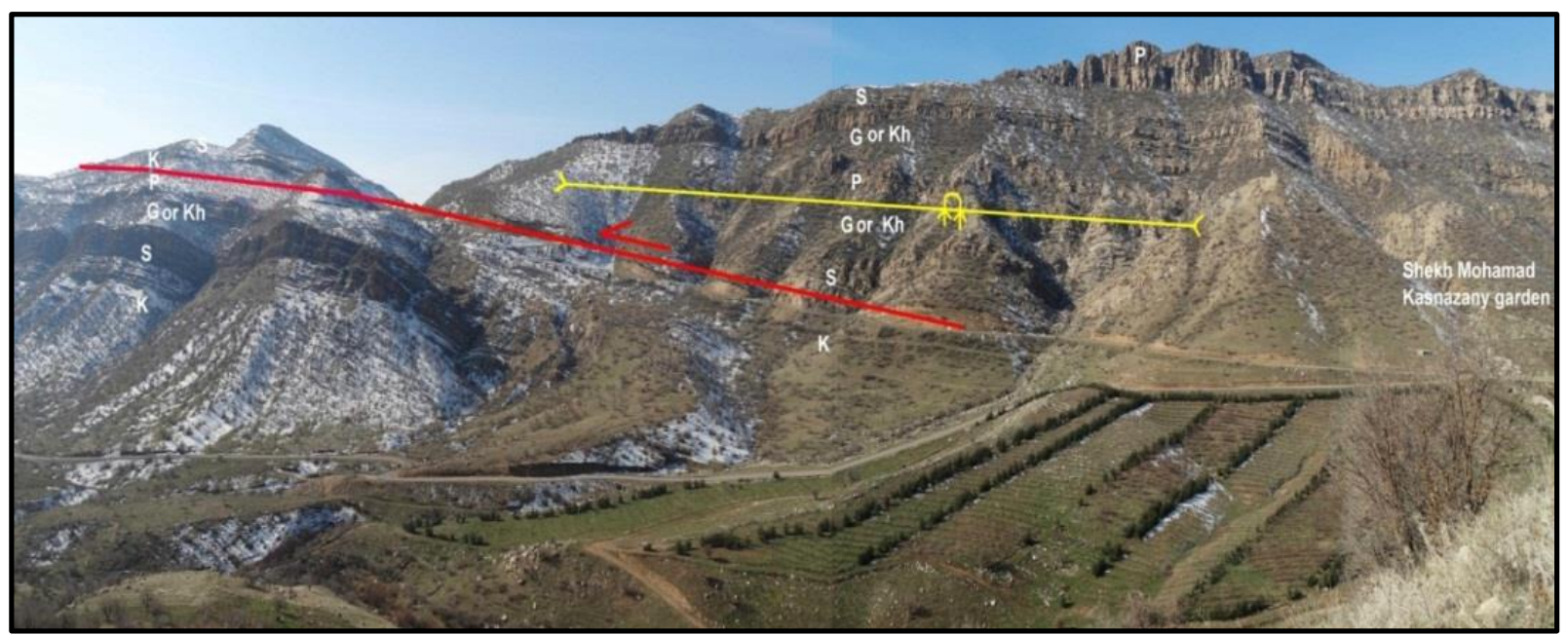

Figure 11. Inner arc of the southwestern limb of the Sagrma anticline along the road between Qaradagh and Sangaw towns, near the Garden of Shekh Mohamd Kasnazany shows the latral thrust and overturned sycline

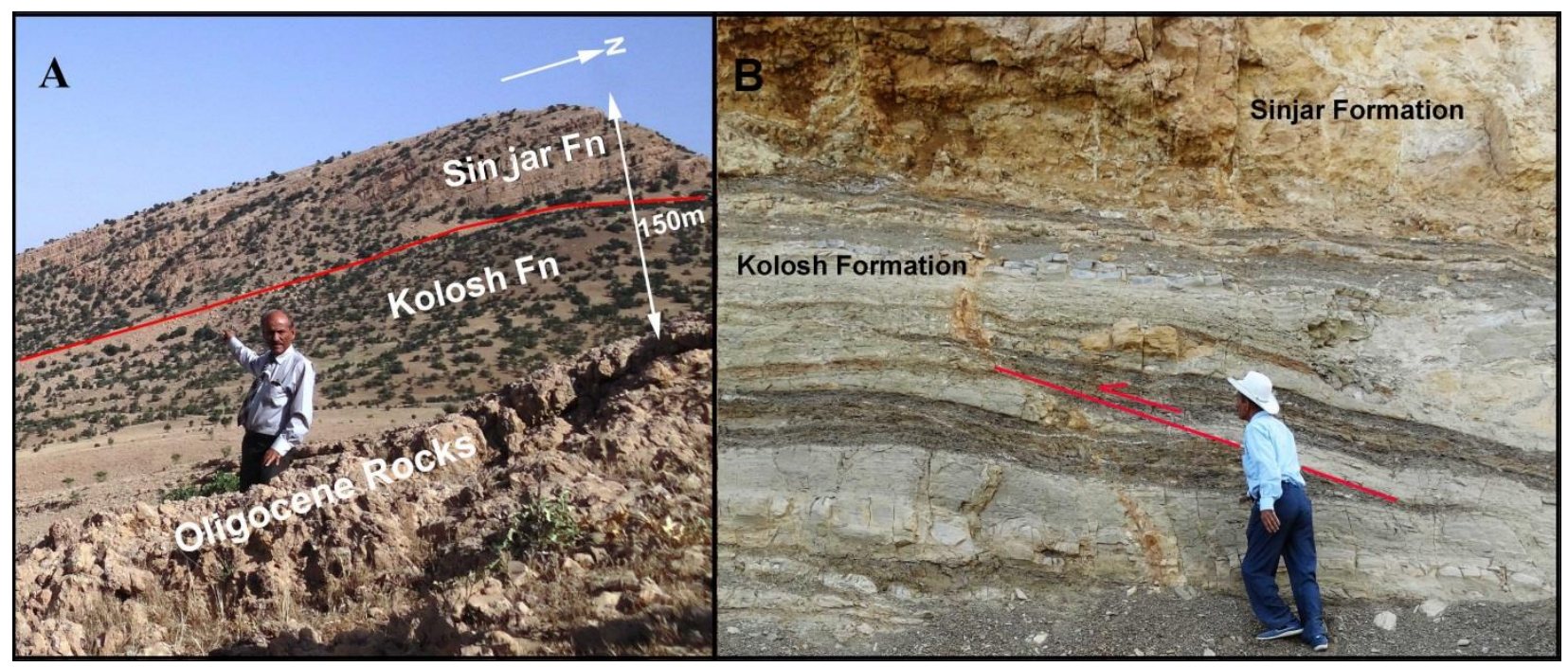

Figure 12. A) Stratigraphic support of the lateral thrust which shows resting of Kolosh Formation - on the

Oligocene rocks. B) small scale lateral thrust of the Hanara Fault at the southwestern limb of the Sagrma anticline along the road between Qaradagh and Sangaw towns, near the Garden of Shekh Mohamd Kasnazany 


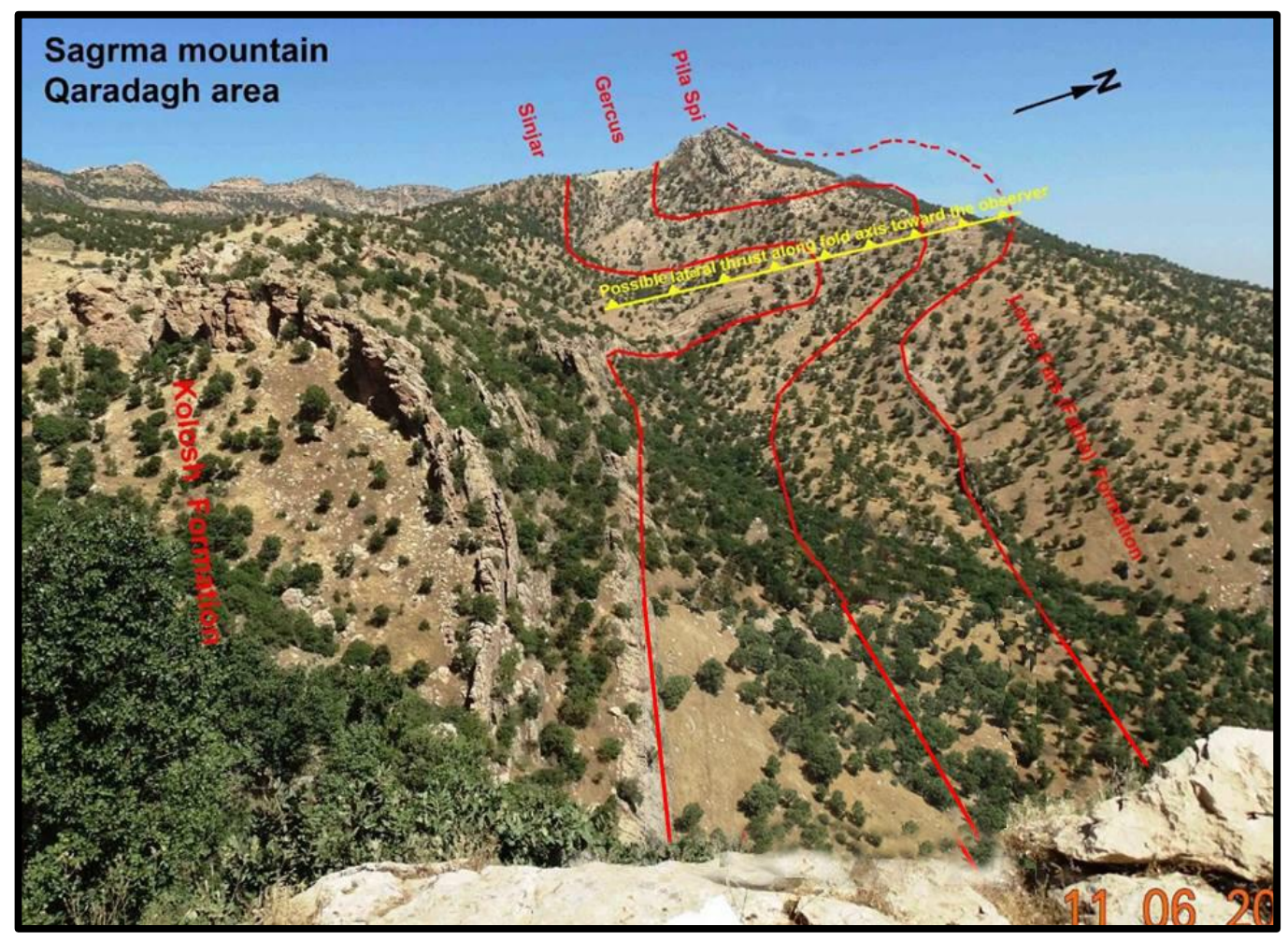

Figure 13. The outer arc of the northeastern limb of the Sagrma anticline to west of the road between Qaradagh and Sangaw towns, shows overturned sycline and anticline with possible a latral thrust

\subsection{Minor Folds}

On the published geological maps (see Sissakain, 2000 and Ma,ala , 2008) and Google image, the Sagrma (or Qaradagh) anticline appears as simple and single anticline. But during field survey on the anticline, many smaller synclines and anticlines are found. Actually, Sagrma anticline is modulated, at least, by four minor folds (parasitic folds) by which the name of the Sagrma anticline can be changed to Sagrma anticlinorium. Due to soil and forest cover, the minor folds cannot be mapped in most parts of anticline while in the northwestern, middle and southeastern ends they are clear and well expressed in the field (Fig.5B, 14 and15). It is possible that anticline is originally formed from one low amplitude anticline but during progressive shortening and limb rotation, they were uplifted and refolded by which it obtained the present shape which shows steeper northeastern limb and gentler southwestern one. This steepness, is due to the thickening of the carbonate (competent) units on the latter limb along which the claystone and marl of Gercus Formation (one the former limb) have changed laterally to carbonate of Khurmala Formation (Fig. 5 and 11). On the northeastern and southwestern limb the type of the miner fold are $\mathrm{S}$ and $\mathrm{Z}$ type folds respectively (Fig. 14A and 15 and 16).

The presence of the lateral thrust along the anticline may be attributed to the presence of the minor folds. These miner folds exist more or less as bulges on the surface of the main Sagrma anticline and they are easily dislocated in their places as lateral thrusts by tectonic stress. 


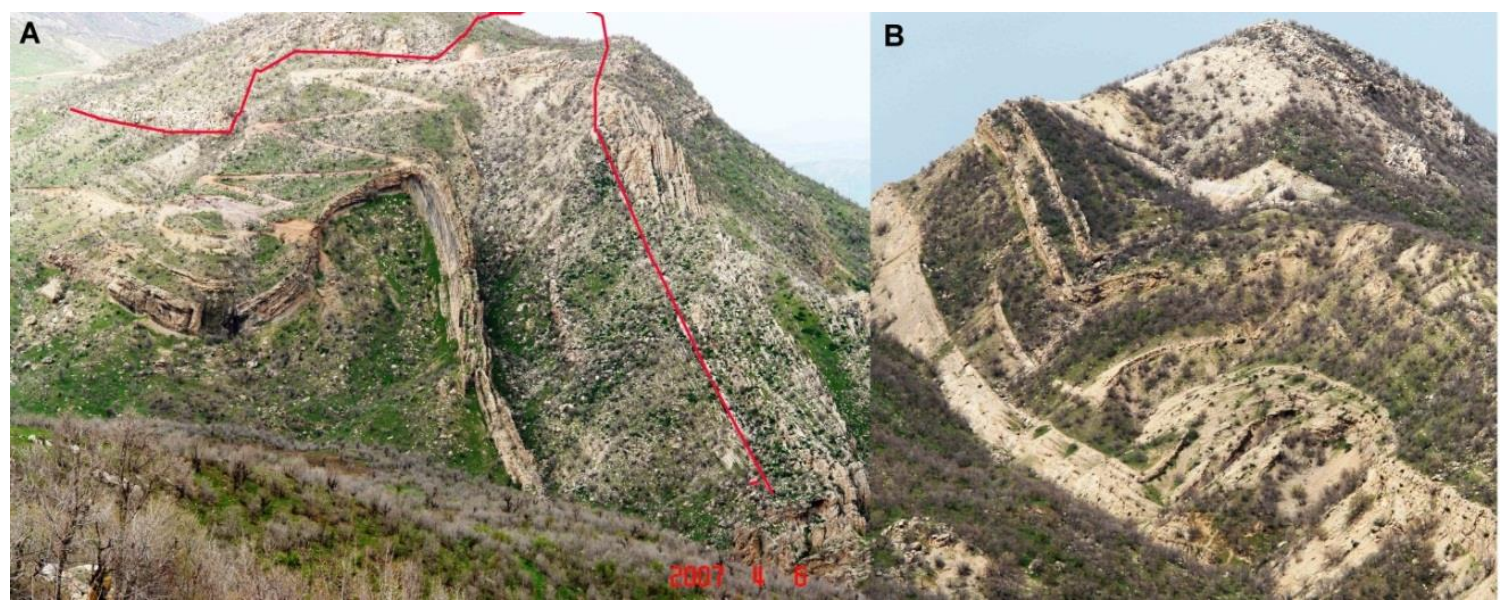

Figure 14. Two miner folds on the northeastern limb of the Sagrma anticline which has the general shape of letter $\mathrm{S}$

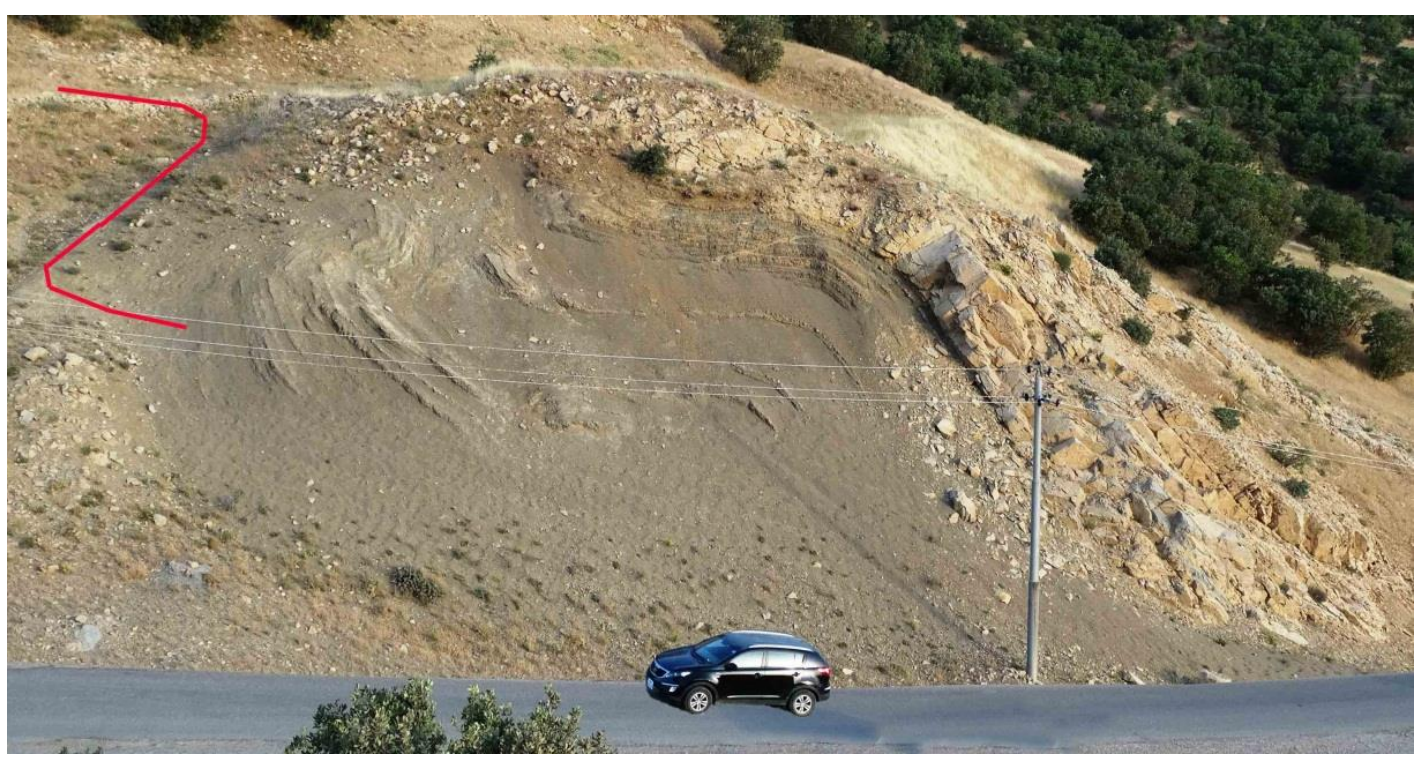

Figure 15. Minor folds in Kolosh and Sinjar Formations on the southwestern limb of the Sagrma anticline which has the general shape of letter $\mathrm{Z}$

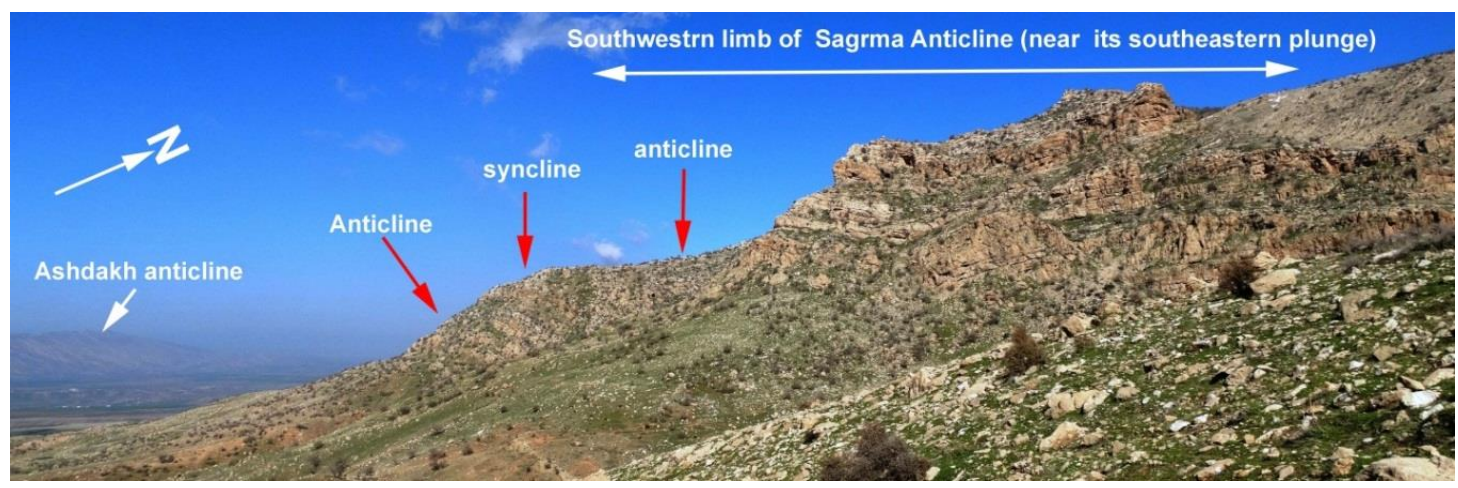

Figure 16. Several folds in the Pila Spi Formation on the southwestern limb of Sagrma anticline at its southeastern plunge and near Darawari Saru village

\section{Conclusions}

1-The previously studied Sagerma and Avanah Formation, are not recorded in the present study 
2-Gercus formation of the northeastern limb is facially changing to Khurmala Formation on the southwestern limb.

3-The previous growth strata is not observed in the present study.

4-The southwestern limb is thicker due to facies change and repetition by faulting

5 -The anticline is formed by detachment and limb rotation

6-It is possible that the absence of oil in the core of the anticline is attributed to its squeezing by limb rotation

7-The anticline is modulated by many superimposed smaller folds, therefor it can be called anticlinorium

8- The anticline is further deformed by lateral thrusts

\section{Competing Interests}

The authors declare that they have no competing interests.

\section{References}

AL-Hakari, S. H. S. (2011). Geometric Analysis and Structural Evolution of NW Sulaimani Area, Kurdistan Region, Iraq (Unpublished doctoral dissertation) University of Sulaimani, Kurdistan region, Iraq.

Al-Husseini, M. I. (2008) Launch of the Middle East Geologic Time Scale. GeoArabia, 13(4).

Ameen (or Lawa), F. A. (2008). Sequence Stratigraphy and Basin Modeling of the Eocene Succession from Kurdistan Region, Northeastern Iraq. AAPG Search and Discovery Article \# 90077, GEO 2008, Middle East Conference and Exhibition, Manama, Bahrain.

Ameen, B. M. (2006). Sequence Stratigraphy of Gercus Formation (Middle Eocene) in Sulaimaniya Area, Northeastern Iraq. Iraqi Journal of Earth Science, 6(2), 23-32.

Baba Shekh, S. M. R., (2001). Hydrogeochemisry of some Springs in Sangaw-Chamchamal area (Unpublished master. thesis), University of Baghdad, $150 \mathrm{p}$.

Buday, T. (1980). Regional Geology of Iraq: Vol. 1, Stratigraphy. In: I.I.M., Kassab and S.Z., Jassim (Eds.). GEOSURV, Baghdad, Iraq, 445pp.

Jassim, S. Z., \& Goff, J. (2006) (Eds.). Geology of Iraq. Dolin, Prague and Moravian Museum, Burno.

Bellen, R. C. van Dunnington, H. V., Wetzel, R., \& Morton, D. (1959) Lexique Stratigraphique, Interntional. Asie, Iraq, 3(c. 10a), 333 p.

Dunnington, H. V. (1958) Generation, migration and dissipation of oil in Northern Iraq. Arabian Gulf, Geology and productivity. AAPG Foreign Reprint Series No. 2.

Energy Pedia news. (2015). Iraq: Vast Exploration provides initial resource assessment for the Qara Dagh Block, Kurdistan. Retrieved from http://www.energy-pedia.com/news/iraq/vast-exploration-provides-initialresource-assessment-for-the-qara-dagh-block--kurdistan

Ghafor, I. M., Karim, K. H., \& Sissakian, V. (2014). Biostratigraphy of Oligocene succession in the High Folded Zone, Sulaimani, Kurdistan Region, Northeastern Iraq, GeoArbia, Springer, 7(9), 3599-36102.

Ghafur, A. A. (2012). Sedimentology and reservoir characteristics of the Oligocene-Early Miocene carbonates (Kirkuk Group) of southern Kurdistan (Unpublished doctoral dissertation) School of Earth and Ocean Sciences, Cardiff University.

Ibrahim, A. O. (2009). Tectonic style and evolution of the NW segment of the Zagros Fold-Thrust Belt, Sulaimani Governorate, Kurdistan Region, and NE Iraq (Unpublished doctoral dissertation) University of Sulaimani, College of Science, 187p.

Karim, K. H. (1997). Stratigraphy of the Sartak-Bamo area, Northeastern Iraq. Journal of Iraqi Geological Society.

Karim, K. H., \& Sulaiman, S. H. (2012). Origin of lateral thrust in Mawat Area, Kurdistan, NE Iraq. Petroleum and Mineral Resources, 11, WIT Transactions on Engineering Sciences (81), WIT Press.

Karim K. H., Khanaqa, P. A., Ismail, K. I., \& Sissakian, V. (2012). Facies analysis of the Oligocene succession on the Sharwaldir anticline, NE of the Kalar Town, NE-Iraq. Iraqi Bulletin of Geology and Mining, 8(2), $1-19$.

Khanaqa, P. A. (2012). Interpretation of new facies in the Pila Spi formation (Middle-Upper Eocene), Sulaimanyia area, NE Iraq. Iraqi Journal of Geology and Mining, GEOSURV, 7(3), 33-45. 
Lawa, F. A. A., \& Ghafur, A. A. (2015). Sequence stratigraphy and biostratigraphy of the prolific late Eocene, Oligocene and early Miocene carbonates from Zagros fold-thrust belt in Kurdistan region. Arab J Geosci, http://dx.doi.org/10.1007/s12517-015-1817-4

Lawa, F. A. (2004). Sequence stratigraphic analysis of the middle Paleocene-Middle Eocene in the Sulaimani District (Kurdistan Region). (Unpublished doctoral dissertation), University of Sulaimani, Iraq.

Lawa, F. A., Koyi, H., \& Ibrahim, A. (2013). Tectono-stratigraphic evolution of the NW segment of the Zagros Fold-Thrust Belt, Kurdistan, NE Iraq. Journal of Petroleum Geology, 36(1), 75-96.

Lawa, F. A. (2008). Sequence Stratigraphy and Basin Modeling of the Eocene Succession from Kurdistan Region, Northeastern Iraq (Abstract). GEO 2008-Middle East Conference and Exhibition, March 2-5, 2008, Manama, Bahrain.

Lawa, F. A., \& Albayati, F. A. (2008). Sequence stratigraphy, facies associations and petroleum systems of Maastrichtian, Selandian, Thanetian, Ypresian and Lutetian successions from Kurdistan region, northeast Iraq. GeoArabia, 12(2), 208 (abstract).

Ma,ala, K. (2008). Geological Map of Sulaimaniya Quadrangle Sheet No.1-38-3, GEOSERV, Baghdad.

Mitra, S. (2003). A unified kinematic model for the evolution of detachment folds. Journal of Structural Geology, $25,1659-1673$.

Omar, A. A, Lawa, F. A., \& Sulaiman, S. H. (2015). Tectonostratigraphic and structural imprints from balanced sections across the north-western Zagros fold-thrust belt, Kurdistan Region, NE Iraq. Arab J Geosci, http://dx.doi.org/10.1007/s12517-014-1682-6

Sissakian, V. K. (2000). Geological Map of Iraq, scale 1:1000000, 3rd edition, GEOSURV, Baghdad.

\section{Copyrights}

Copyright for this article is retained by the author(s), with first publication rights granted to the journal.

This is an open-access article distributed under the terms and conditions of the Creative Commons Attribution license (http://creativecommons.org/licenses/by/3.0/). 